\title{
The Debate on Medieval Western Christian Dualism through the Prism of Slavonic Pseudepigrapha
}

\author{
Yuri Stoyanov
}

School of Oriental and African Studies, University of London ys3@soas.ac.uk

\begin{abstract}
The study of the Old Slavonic pseudepigrapha has assumed wider significance in wider areas of Jewish and Christian religious history after recent research has indicated their importance for the investigation of early Jewish and Christian apocalypticism, Gnosticism and the Jewish Merkabah tradition. The article intends to present the state of evidence and research of the influx of early Jewish and Christian parabiblical narratives and notions in western medieval heretical milieux (via the transmission of Slavonic apocryphal traditions through Eastern dualist channels). The parabiblical narratives or elements of earlier pseudepigraphic texts in the sources for Catharism have been largely downplayed or ignored in the current debates on medieval Western heresy. However, they should be reintegrated in the central ground of these debates, as they provide vital clues to medieval dualist stances on Scripture and the exegetical and compilatory techniques in recasting biblical and parabiblical material in medieval theological and literary environments
\end{abstract}

\section{Keywords}

pseudepigrapha - apocrypha - dualism - Slavia orthoodoxa - byzantium - heresy literacy - bogomilism - catharism

The trajectories and dynamics of the use and exegesis of scriptural and parascriptural material in medieval Christian dualism was not among the principal areas of early scholarly investigation of medieval European heresy and heterodoxy. Early scholarly study of the medieval dualist movements and their theologies (namely, Paulicianism, Bogomilism and related groups in the Eastern 
Christendom, as well as Catharism in Western Christendom) was still marked by the powerful and enduring legacy of Catholic-Protestant polemics over the doctrinal and cultic traditions of medieval dissenting and reformist groups (including the Christian dualist communities). Accordingly, much of the subsequent polemical and historiographic controversies and conflicting approaches in the early modern period were rooted in the Catholic-Protestant divide in the sixteenth century. These confessionally-coloured approaches were to be gradually and largely superseded in the the nineteenth and twentieth centuries by more source-based and historical-critical research, triggered by and focused on the publication of a series of major primary sources for the history and teachings of medieval European heresies and the Christian dualist movements, in particular.

Significantly, the first stages of the process of the publications and critical study of the so-called Old Church Slavonic pseudepigrapha in the nineteenth century brought an increasing awareness of the intricate intertextual relationships between the varied and generally widely disseminated pseudepigraphic literature in Slavia Orthodoxa and medieval Eastern Christian dualism. As such wide-ranging circulation and assimilation of pseudepigraphic literature did not occur in early to high medieval Western Christian cultures these specific relationships between Eastern Christian pseudepigraphy and dualist heresy became the subject of scholarly analysis and debate much earlier than in the case of any comparable corresponding developments in medieval Western Christian settings.

The nineteenth-century study of medieval Eastern Christian dualist currents thus had its own distinctive dynamics, as the availability of new relevant primary sources began to throw new light on the origins and spread of Paulicianism in early medieval Armenia (a complex religious and contact and conflict zone during this period) and Byzantium, as well as the rise of Bogomilism in the tenth-century newly (re-) Christianized Balkans. On one hand, an increasing amount of published primary source material clearly showed that medieval Eastern Christian dualist heretics (especially the Bogomils) applied a variety of rhetorical and exegetical strategies to scriptural and para-scriptural texts to authenticate, elaborate and elucidate their belief systems. On the other hand, the fashionable influential ideological and intellectual currents of nineteenth-century Eastern Europe, ranging from Slavophilism to nationalism, also had a defining impact on the early study of medieval Eastern Christian dualism. When applied in medieval religious history, these Slavophile as well as the narrow ethno-centric and simplistic socio-economic approaches did not have any real concern with or intention to explore the types of hermeneutics adopted by medieval dualist heretics to deal with and re-interpret scriptural and 
para-scriptural literature. However, the sheer accumulation of collections of or individual medieval Slavonic pseudepigraphic texts from the 1840 s onwards transformed the field to the extent that made it impossible even for the most rigid of the institutionalized historiographic Marxist schools of the Eastern Bloc to avoid the problematic of the inter-relations between pseudepigraphy and medieval heresy.

The significance and implications of these inter-relations have been made patently evident with the publication of the vital internal source for both medieval Eastern and Western Christian dualism, the apocryphon, Interrogatio Iohannis, ${ }^{1}$ which started to attract close scholarly attention against the background of the early expansion of text-critical research on the Slavonic pseudepigrapha. As the amount of concrete and credible textual data of these textual inter-connections gradually expanded, the frequently used and often uncritically applied versions of the popular contact-diffusion model in regard to medieval Eastern Christian dualism began to look increasingly problematic and superficial. Traditionally and influentially employed to reconstruct sectarian historical connections and pedigrees, in the case of Eastern Christian dualist communities this model encounters a series of grave and, at present, unsurmountable difficulties. These stumbling blocks in research are largely the outcome of a number of crucial and substantial gaps and ambiguities in the surviving evidence of the doctrinal sources of Paulicianism and Bogomilism as well as various stages of their history in the medieval and early Ottoman eras. These problems certainly cannot be resolved by fully or partially taking up medieval heresiological Catholic or Eastern Orthodox definitions of medieval du-

1 The pseudepigraphon is preserved only in two main version; the first version represents a manuscript once in the archives of the Inquisition at Carcassonne but subsequently destroyed: it survives in two late manuscripts and one printed text. Published for the first time by J. Benoist, Histoire des Albigeois et des Vaudois ou Barbets, vol. 1, Paris, 1691, pp. 283-296; one of the above late manuscripts, that from the Dôle library, is used as a representative of the Carcassonne version in the most recent critical edition of text, E. Bozóky, Le Livre secret des cathares, Paris, 1980, pp. 41-94. The second version is extant solely in a manuscript preserved in the National Library of Vienna, dating from the late twelfth/early thirteenth century. The Carcassonne version was published alongside the Vienna version by М. Соколов, "Материалы и заметки по старинной славянской литературе. Выпуск 3. VII, Славянская Книга Еноха Праведнаго. Тексты, латинский перевод и исследование," Чтения в Обществе истории и древностей российских [M. Sokolov, "Materials for and Observations on the Slavonic Book of Enoch the Righteous. Texts, Latin Translation, Studies," Publications of the Society for the Study of Russian Histiory and Antiquities ] 4 (1910), pp. 165-175; also by Й. Иванов, Богомилски книги и легенди [I. Ivanov, Bogomil Books and Legends], Sofia, 1925, pp. 73-87; and in the most recent critical edition of text, Bozóky, Le Livre secret, pp. 41-94. 
alist heresy as a direct heir to or merger of late antique Gnostic traditions (Manichaean or other). Unsupported by internal source material, such approaches remain imprecise and ahistorical.

The broader and expanding source-base makes it more and more evident that the sources for for Paulician and Bogomil dualism should be sought not only in pre-existing heretical and heterodox traditions and the conjectured historical impact of antecedent dissenting religious communities. It is at least equally possible that the founders and heresiarchs of both movements could have conceptualized their theologies and doctrinal traditions autonomously, generally without any such external influences and direct contacts with earlier heretical groups or individuals. ${ }^{2}$ This is all the more so since newly opened venues for research have widened our knowledge of the scope and impact of diverse undercurrents of heresy, heterodoxy, alternative demonology and dualist-leaning developments in lay and monastic mysticism in Byzantine and Eastern Christian cultures which could have variously interacted with or contributed to the anti-somatic, anti-cosmic and docetic features of Paulician and Bogomil dualism. ${ }^{3}$

In the case of Paulician teachings the present state of evidence and research does not permit as yet an adequate assessment of the possible place of pseudepigraphical literature in Armenia and Byzantium in their initial or later phases. On the contrary, medieval accounts of Bogomil doctrines present partially preserved parabiblical embellishments of the Genesis creation and flood stories, apocryphal and heretical satanologies and Christologies which comprise a number of motifs and narratives which cannot be readily traced to the teachings of earlier medieval dissenting, heterodox and heretical movements or circles. Significantly enough, these elements and para-biblical accounts find close and evident parallels (which bear clear signs of immediate intertextual relations) in the extensive corpus of multifarious pseudepigraphic works which were translated and disseminated in the early phases of Slavia Orthodoxa's written culture shaped under the impact of the missions of St Constantine-Cyril the Philosopher and St Methodius and the consequent appearance of the Slavonic versions of the Scriptures, liturgy and alphabet.

2 Cf. J. Hamilton and B. Hamilton, "Historical Introduction," in: Christian Dualist Heresies in the Byzantine World c. 650-c. 1450, eds. J. Hamilton and B. Hamilton, assist. ed. Y. Stoyanov, Manchester, 1998, pp. 7-8; Y. Stoyanov, The Other God. Dualist Religions from Antiquity to the Cathar Heresy, London, 2000, pp. 125-129.

3 See the summary of recent research on this problematic in Y. Stoyanov, "Pseudepigraphic and Parabiblical Narratives and Elements in Medieval Eastern Christian Dualism and Their Implications for the Rise and Evolution of Catharism," in: Cathars in Question, ed. A. Sennis, Woodbridge, UK, 2016, pp. 154-156 
These intertextual dependencies betray the clear traces of creative and selective Christian dualist appropriations which also reflect the close links between the making of Bogomil theological concepts (and their auxiliary parabiblical embellishments) and the distinctive processes underpinning the accelerated inception and crystallization of Slavo-Byzantine Orthodox culture and learning in South-Eastern Europe from the last decades of the ninth century onwards. There are various indications that the translations of canonical literature, fostered by the new literary schools of the period, were accompanied by the wide-ranging reception, translation and diffusion of extra-canonical apocryphal literature in these early stages. The extant Slavonic versions of such pseudepigraphic works, for instance, retain linguistic features which confirm that the earliest Slavonic protographs of these translations can be convincingly dated from the late ninth to the eleventh centuries. Symptomatically, medieval Slavonic indexes of forbidden apocryphal books ${ }^{4}$ at times castigate local priests for possessing, translating and circulating such formally censored works in a situation of "canonical ambiguity" which was not only characteristic of these foundational stages of Slavia Orthodoxa's literary culture but persisted well into the Late Middle Ages. ${ }^{5}$

Ultimately, the translation of canonical and extra-canonical texts into a language which was not too disparate from contemporaneous Slavonic vernaculars introduced a novel dynamic into the complex interrelationships between orthodoxy, literacy, heterodoxy and heresy in Eastern Christianity, which had their own characteristic tensions, contrasting in a number of ways with those inherent in medieval Western Christianity. ${ }^{6}$ These specific religious and cultural conditions underlying the genesis of early Slavonic Orthodox theology

4 On the texts and the history of the Slavonic Indexes of Forbidden Books, see, for example, И.И. Порфирьев, Апокрифические сказания о ветхозаветных лицах и событиях [I.I. Porfir'ev, Apocryphal Legends about Old Testament Figures and Events], Kazan, 1872, pp. 142-168; А.И. Яцимирский, Библиографический обзор апокрифов в южнославянской и русской письменности. Выпуск 1, Апокрифы ветхозаветные (A.I. Jatsimirskij, Bibliographical Survey of the Apocrypha in the South Slavonic and Russian Literatures. I. Old Testament Apocrypha] Petrograd, 1921, pp. 1-75; Б.С. Ангелов, Б, “Списъкът на забранените книги в старобългарската литература“[B.S. Angelov, "Spisŭkŭt na zabranenite knigi v starobŭlgarskata knizhnina,"] Izvestiia na instituta za bŭlgarska literatura, 1 (1952), pp. 107-159.

5 See the up-to-date discussion of this phenomenon in A. Kulik and S. Minov, "Introduction," in: Biblical Pseudepigrapha in Slavonic Traditions, eds. A. Kulik and S. Minov, Oxford, 2016, pp. xxiv-xxvi.

6 See the contributions to the study of various aspects of these interrelationships in Western Christendom in Heresy and Literacy 1000-1530, eds. P. Biller and A. Hudson, Cambridge, 1994. 
and learning (with the entrance of para-scriptural narratives and motifs via the translated apocryphal works from late antiquity) generated an environment especially conducive to the procreation of doctrinal deviances and a kind of general "heterodoxisation".

Such heterodoxisation was made even more possible by the eclectic theological provenance of the newly translated Slavonic versions of late antique apocryphal writings some of which retained concepts, motifs and imagery which were bordering on and approaching Gnostic (or proto-Gnostic) and dualist doctrinal traditions. Indeed the unorthodox pedigree and affinities of such notions were among the principal reasons for the marginalization and prohibition of the respective apocryphal writings by late antique and early medieval church authorities, but in the receptive climate of early Slavo-Byzantine cultures they could enjoy a kind of lasting medieval afterlife.

The early accessibility and circulation of such pseudepigraphic writings in clerical, monastic and lay learned milieux certainly set the stage for emerging theological ambiguities, controversies and heterodoxies, while the latter could be amplified by narratives and motifs, acquired literally or in modified versions from the growing corpus of translated apocrypha. As shown in the early records of Bogomil New Testament exegesis, selected elements of such appropriated pseudepigraphic expositions and topoi could be synthesized with inventive inverse scriptural exegesis and allegorical interpretations. Significantly, such a combination of scriptural exegesis and parabiblical narratives could be preached and disseminated in the vernacular, which in the climate of nascent Christianization, certainly enhanced further the scope of its appeal and impact (particularly, given the importance of orality and oral transmission of tradition in contemporaneous Slavonic cultures).

Thus apart from the possible impact of earlier heretical presence and missions in South-Eastern Europe, ${ }^{7}$ the rise of monasticism (with its mystical and ascetic currents, including the emulation of apostolic life), the assimilation of pseudepigraphic literature into early Slavia Orthodoxa certainly played a decisive role in the formation of the new medieval version of Eastern Christian dualism, Bogomilism. The study of the varied interrelations between SlavoByzantine pseudepigraphical literature and Bogomilism evolved with the expansion of the publications and text-critical study of the Slavonic recensions

7 See, for example, Peter of Sicily's report that c. 869-870 Anatolian Paulician communities were planning to send missions to the newly Christianized Bulgarian kingdom, Peter of Sicily, Historia Manichaeorum qui Pauliciani dicuntur, ed. D. Papachryssanthou, in: C. Astruc et al., "Les Sources grecques pour l'histoire des Pauliciens d'Asie Mineure," TM, 4 (1970), pp. 5, 9 . 
of a series of important pseudepigrapha in the second half of the nineteenth century. Some of these writings like The Book of the Secrets of Enoch (2 Enoch), ${ }^{8}$ The Ladder of Jacob and The Apocalypse of Abraham, ${ }^{9}$ are preserved only in their Slavonic versions; other texts such as the Slavonic recensions of The Vision of Isaiah ${ }^{10}$ and The Greek Apocalypse of Baruch (3 Baruch),, ${ }^{11}$ have retained

8 Earlier discussions of the textual evidence and history of the pseudepigraphon (and collation of the relevant texts) may be found in Соколов, "Материалы и заметки," and Иванов, Богомилски книги, pp. 165-191. For more recent summaries of and perspectives on the ongoing textual debates and the theological and literary provenance of the apocalypse, see F. Andersen, "2 (Slavonic Apocalypse of) Enoch," in: The Old Testament Pseudepigrapha, ed. J.H. Charlesworth, 2 vols., New York, 1983-1985, vol. 1, pp. 91-223; A. Orlov and G. Boccaccini, New Perspectives on 2 Enoch. No Longer Slavonic Only, Leiden-Boston, 2012; G. Macascill, The Slavonic Texts of 2 Enoch, Leiden-Boston, 2013. For a bibliography of the editions, translations and studies of 2 Enoch, see A. Orlov, "Selected Bibliography on the Transmission of the Jewish Pseudepigrapha in the Slavic Milieux," in A. Orlov, Selected Studies in the Slavonic Pseudepigrapha, Leiden, 2009, pp. 222-243.

$9 \quad$ Like 2 Enoch and The Ladder of Jacob, The Apocalypse of Abraham is extant only in Slavonic manuscripts. Recent critical editions of the apocalypse were published separately by B. Philonenko-Sayar and M. Philonenko, L'Apocalypse d'Abraham, Introduction, text slave, traduction et notes, Paris, 1981, and by R. Rubinkiewicz, L'Apocalypse d'Abraham en vieux slave: Introduction, text critique, traduction et commentaire, Lublin, 1987. The important textual critical investigation of the apocalypse of A. Kulik, Retroverting Slavonic Pseudepigrapha: toward the Original of the Apocalypse of Abraham, Atlanta, GA, 2004, includes an English translation of the text (pp. 9-37); the study of the theology, angelology, demonology and eschatology of the pseudepigraphon has been pursued in a series of articles of Andrei Orlov, see, for example, his contributions in Orlov, Selected Studies, pp. 21-93; idem, Divine Manifestations in the Slavonic Pseudepigrapha, New Jersey, 2009, pp. 155-177, 203-237; idem, Dark Mirrors: Azazel and Satanael in Early Jewish demonology, New York, 2011, pp. 11-85. For a bibliography of the editions, translations and studies of The Apocalypse of Abraham, see Orlov, "Selected Bibliography," pp. 246-256.

Like the Latin Visio Isaiae (the second Latin translation of the work) the Slavonic version of the apocalypse contains only chapters 6-11 of the Martyrdom and Ascension of Isaiah (a pseudepigraphon which brings together important Jewish and early Christian traditions about Isaiah), and generally shares the same textual tradition with this Latin translation, which clearly represents a separate recension of the pseudepigraphon. For an up-to-date commentary and discussion of the family stemma of the manuscripts along with a new edition of Slavonic text see A. Giambelluca Kossova, "Visio Isaiae.Versione paleobulgara," in: Ascensio Isaiae: Textus, ed. P. Bettiolo et al., Turnhout, 1995, pp. 235-319. For a bibliography of the editions, translations and studies of the Slavonic version of the The Vision of Isaiah, see Orlov, "Selected Bibliography," pp. 276-278.

While the apocalypse has been a subject of academic scrutiny since the end of the nineteenth century, the study of The Greek Apocalypse of Baruch (3 Baruch) entered a new phase after the critical editions of its Greek version by J.-C. Picard,"Apocalypsis Baruchi 
important readings and textual traditions which on a variety of occasions are more authentic and closer to the lost original protograph than those represented in other redactions (Greek in the case of 3 Baruch, etc.). Apart from their utilization in medieval literary and religious contexts, the early exploration and attempts to stratify the different redactional layers of their medieval recensions and isolate the oldest ones, was already beginning to demonstrate their wider significance for a number of growing vital fields in the study of early Judaism and Christianity. More recent and ongoing research has been confirming this significance, broadening it further to include their relevance to the exploration of early Jewish and Christian apocalypticism, early Jewish mysticism and the complex of overlapping distinct motifs they share with rabbinic literature. ${ }^{12}$ The analysis of the potential channels of transmission of late antique pseudepigraphic literature into the early Slavonic Orthodox written tradition has also widened to integrate approaches and arguments for nonByzantine mediation of some of these texts and direct translations from Syriac into Slavonic in some cases. ${ }^{13}$

Graece," in: idem, Testamentum Iobi, Apocalypsis Baruchi Graece, Leiden, 1967, pp. 81-96. and its Slavonic version by H.E. Gaylord, The Slavonic Version of 3 Baruch, PhD diss., Hebrew University of Jerusalem, 1983. It was substantially enhanced by subsequent major studies of the apocalypse by D.C. Harlow, The Greek Apocalypse of Baruch (3 Baruch) in Hellenistic Judaism and Early Christianity, Leiden, 1996, and A. Kulik, 3 Baruch: Greek-Slavonic Apocalypse of Baruch, Berlin-New York, 2010, with a very valuable new English translation of, and commentary on, the apocalypse, pp. 89-386. For a bibliography of the editions, translations and studies of 3 Baruch, see Orlov, "Selected Bibliography," pp. 278284 .

See the latest discussion of the state of research and evidence in this area of study in Kulik and Minov, "Introduction" (which contains the most recent and up-to-date discussion of the state of research and evidence in the area of the Slavonic Pseudepigrapha); for similar recent reappraisals cf. L. DiTommaso and Ch. Böttrich, "Old Testament Apocrypha in the Slavonic Tradition," in: The Old Testament Apocrypha in the Slavonic Tradition: Continuity and Diversity, eds. L. DiTommaso and Ch. Böttrich, Tübingen, 2011, pp. 1-5; J.H. Charlesworth, "The Uniqueness and Importance of Slavonic Pseudepigrapha," in: The Old Testament Apocrypha, eds. DiTommaso and Böttrich, pp. 5-12.

See the presentation of the evidence and arguments for such translations in B. Lourié,

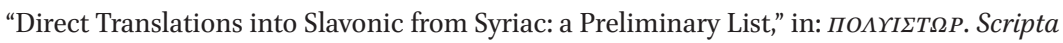
Slavica. Mario Capaldo Dicata, ed. C. Diddi et al., Moscow-Rome, 2015, pp. 161-169; see also В. Лурье, “Около Солунской легенды: из истории миссионерства в период монофелитской унии" [В. Lourié, "The Legend of Thessaloniki: towards the History of Mission in the Period of the Mohotheletic Unia"] in: Славяне и их соседи, вып. 6, Moscow, 1996, pp. 23-52; B. Lourié, "The Syriac Ahiqar, Its Slavonic Version, and the Relics of the Three Youths in Babylon," Slověne, 2 (2013), No 2, pp.64-117; idem, "Почему «Славянский» Енох оказался в Нубии," [“Why was the Slavonic Enoch Circulated in 
At the same time, the complex textual history of most of these texts, which have been translated, edited and circulated in different cultural and religious milieux over lengthy period of time, poses a number of serious methdological problems. Some of these principal problems arise from the presence (though unevenly attested among the writings) of secondary and medieval interpolations and intrusions in the texts. The identification of this secondary material, its literary, ideological and religious background as well as its possible dating require by necessity the application of interdisciplinary methodologies. These methodologies need to include meticulous philological and palaeographic analyses and contextualization of early pseudepigraphic material in Byzantine and Slavonic Orthodox environments, while drawing at the same time on the latest advances in biblical criticism and scholarship on early and medieval Judaism and Christianity.

Bringing these disciplines together in the study of the relevant medieval Slavonic material has had major implications for better understanding of the relationship between Bogomilism and pseudpigraphic literature in the Slavo-Byzantine world. This is especially the case in respect to Bogomil pseudepigraphy itself and the debates on the chronology of this relationship and the contrasting "wider" or "narrower" definitions of the term "Bogomil apocryphon". ${ }^{14}$ Another area that has profited from these interdisciplinary ap-

Nubia"] in: Археографические и источниковедческие аспекты в изучении истории России, отв. ред. А.Х. Элерт, [Archeographic and Source-Critical Aspects of the Study of the Russian History, ed. A. Kh. Elert], Novosibirsk, 2016, pp. 35-43.

14 For the traditional and influential exposition of the theory that the Bogomil scribes edited a number of Old Church Slavonic pseudepigrapha, see Иванов, Богомилски книги и легенди; cf. the approaches to the problematic in D. Obolensky, The Bogomils. A Study in Balkan Neo-Manichaeism, Cambridge, 1948, pp. 154-155, 226, 228, 272, 281, 282 ff.; HenriCh. Puech and A. Vaillant, Le Traité contre les Bogomiles de Cosmas le prêtre, Paris, 1945, p. 130 ff.; S. Runciman, The Medieval Manichee. A Study of the Christian Dualist Heresy, Cambridge, 1947, pp. 77-78, 84; for more recent reconstructions of the interrelations between Bogomilism and Slavo-Byzantine pseudepigraphic literature, generally reinstating Ivanov's position see, for example, Д. Ангелов, Богомилството в България [D. Angelov, Bogomilism in Bulgaria], 3rd edn, Sofia, 1980, pp. 63, 66, 208, 212-214, 351-352; Ю.К. Бегунов, Козма пресвитер в славянских литературах [Iu. Begunov, Presbyter Cosmas in Slavonic Literatures], Sofia 1973, pp. 245-248; and the recent revival of Ivanov's thesis (and his wider definition of "Bogomil apocryphon” by П. Димитров, „Богомил“ and „Богомилски сказания и легенди“ [Р. Dimitrov, "Bogomil” and “Bogomil Stories and Legends]" in: Петър Черноризеu [Petŭr Chernorizets], Shumen, 1995, pp. 116-167 and 140167; Д. Димитрова, “Тайната книга на богомилите в системата на старобългарската литература" [D. Dimitrova, “The Secret Book of the Bogomils in the System of Old Bulgarian Literature"], Preslavska knizhovna shkola, 1 (1995), pp. 59-69. See the critiques of this 
proaches concerns the evident parallels between certain Bogomil teachings and apocryphal as well as popular cosmogonic traditions which have survived into the modern period (with all their analogies in archaic Eurasian cosmogonies). ${ }^{15}$

In earlier stages of research and mainly in medievalist studies sufficient attention was not paid to the actual historical and theological provenance of the cosmological and apocalyptic material shared in the Old Church Slavonic pseudepigrapha and medieval Christian dualist doctrinal traditions. More recently, however, the scope of investigation has widened to include a research focus on the earlier and continued heterodox and heretical interest in some of these pseudepigrapha. Consequently, more attention has been devoted to the various dualist-and Gnostic-leaning tendencies in their texts which were already subjected to heterodox interpretations and modifications during their earlier transmission and adoption in such sectarian or dissident milieux. A sizeable number of these tendencies allowed more forceful dualist interpretations, which were eventually provided by Christian dualist scribes and editors in the medieval phases of the dissemination of these pseudepigrapha. It was via such channels that this particular pseudepigraphic material found its way (in greatly or slightly modified forms) into a variety of medieval dualist teachings and related popular lore, especially, but not only, in Eastern Christendom.

Further close study of the provenance and use of pseudepigraphical and parabiblical material in medieval Eastern and Western Christian dualist doctrinal, narrative and popular traditions is also of great significance to another expanding and promising area of late antique and medieval historical and literary studies. This is the field of continuing and broadening scholarly projects and endeavours to reassess and improve the methodology and terminology employed in the exploration of the role and typologies of intertextuality and metatextuality in ancient, late antique and medieval pseudepigraphy, apo-

broader understanding of the "Bogomil apocrypha" in É. Turdeanu, "Apocryphes bogomiles et apocryphes pseudo-bogomiles," Revue d'histoire des religions, 138 (1950), pp. 22-52, 176-218; M. Loos, Dualist Heresy in the Middle Ages, Prague, 1974, pp. 84, 85, 88, 134, 143-144, 340; Д. Драгойловић, Богомилство на Балкану и у Малој Азији, Богомилство на православном истоку [D. Dragojlović, Bogomilism in the Balkans and Asia Minor. Bogomilism in the Orthodox East], Belgrade, 1982, pp. 186-195. Сf. Д. Драгойловиќ and В. Antiќ, Богомилството во средновековната изворна граѓa [D. Dragojlović and V. Antić, Bogomilism in Medieval Authentic Material], Skopje, 1978; A. Miltenova, "Littérature apocryphe bogomile et pseudo-bogomile dans la Bulgarie médiévale," Slavica occitania, 16 (2003), pp. 37-54; Stoyanov, "Pseudepigraphic and Parabiblical Narratives," pp. 165-167.

15 On these Eurasian cosmogonies, their dualist tendencies and features, see the analysis of the state of evidence and research in Stoyanov, The Other God, pp. 131-139. 
cryphal and parascriptural literature. Collaborative scholarly initiatives at first aiming to advance reappraisals of the heuristic applicability of the terms "apocryphon" and "pseudepigraphon"16, "rewritten Bible/Scriptures"17 and "parabiblical literature"18, have set the stage for two recent major international interdisciplinary projects which have had a substantial influence on the study of parascriptural and paratextual ancient and medieval literature (and its early modern and modern afterlife).${ }^{19}$ These projects and their published outcomes have generated a number of theoretical and methodological advances and innovations some of which have been fruitfully applied in the field of Old Slavonic cultures, with their rich genres of pseudepigraphic apocryphal

16 See, for example, Ch.C. Torrey, The Apocryphal Literature: A Brief Introduction, New Haven, 1945.

17 G. Vermes, Scripture and Tradition in Judaism: Haggadic Studies, Leiden, 1961, 2nd edn 1973; G.W.E. Nickelsburg, "The Bible Rewritten and Expanded," in: Jewish Writings of the Second Temple Period: Apocrypha, Pseudepigrapha, Qumran Sectarian Writings, Philo, Josephus, ed. M.E. Stone; Assen-Philadelphia, 1984, pp. 89-156; Ph.S. Alexander "Retelling the Old Testament," in: It is Written: Scripture Citing Scripture. Essays in Honor of Barnabas Lindars, eds. D.A. Carson and H.G.M. Williamson, Cambridges, 1988, pp.99-121; G.J. Brooke, "The Rewritten Law, Prophets and Psalms: Issues for Understanding the Text of the Bible," in: The Bible as Book: The Hebrew Bible and the Judaean Desert Discoveries, eds. E.D. Herbert and E. Tov, London, 2002, pp. 31-40; the contributions in Reworking the Bible: Apocryphal and Related Texts at Qumran: Proceedings of a Joint Symposium by the Orion Center for the Study of the Dead Sea Scrolls and Associated Literature and the Hebrew University Institute for Advanced Studies Research Group on Qumran, eds. E.G. Chazon, D. Dimant and R.A. Clements, Leiden, 2008; the relevant contributions in E. Tov, Hebrew Bible, Greek Bible, and Qumran. Collected Essays, Tübingen, 2008. Cf. M.J. Bernstein, "Rewritten Bible': A Generic Category Which Has Outlived Its Usefulness?," Textus, 22 (2005), pp. 169-196.

18 See, for example, H.W. Attridge, T. Elgvin et al., Qumran Cave 4.VII. Parabiblical Texts, Part 1, Oxford, 1994; M. Broshi, E. Eshel, et al., Qumran Cave 4.XIV. Parabiblical Texts, Part 2, Oxford, 1995; D.K. Falk, The Parabiblical Texts: Strategies for Extending the Scriptures among the Dead Sea Scrolls, London, 2007; A. Lange, "The Parabiblical Literature of the Qumran Library and the Canonical History of the Hebrew Bible," in: Emanuel: Studies in Hebrew Bible, Septuagint, and Dead Sea Scrolls in Honor of Emanuel Tov, eds. Sh.M. Paul, R.A. Kraft et al., Leiden, 2003, pp. 305-321; on the use of term 'paratextual', see, for example, A. Lange, "Pre-Maccabean Literature from the Qumran Library and the Hebrew Bible," Dead Sea Discoveries, 13/3 (2006), pp. 277-305.

19 In the Second Degree: Paratextual Literature in Ancient Near Eastern and Ancient Mediterranean Culture and Its Reflections in Medieval Literature, eds. Ph.S. Alexander, A. Lange, and R. Pillinger, Leiden, 2010; Between Text and Text. The Hermeneutics of Intertextuality in Ancient Cultures and Their Afterlife in Medieval and Modern Times, eds. M. Bauks, W. Horowitz, and A. Lange, Göttingen, 2013. 
literatures. ${ }^{20}$ Continuing and expanding these particular research vistas certainly will be of vital significance to the classification of these genres (and their Byzantine Greek antecedents) and reappraising its existing models and dividing lines between quasi-canonical, non-canonical and anti-canonical apocryphal texts, as well as their divergent textual and ideological inter-connections with the Scriptures. ${ }^{21}$

A growing amount of research has been thus shedding further light on the series of important notions in Bogomil diabology, cosmogony, expansions on biblical history, Christology and apocalypticism which have been adopted from earlier pseudepigraphical and parabiblical writings and often subjected to a dualist re-interpretation. While highlighting and illustrating the scope of this indebtedness of Bogomil dualism to earlier parascriptural works in some of its principal spheres, the extant evidence also suggests that being at its core, Bogomil diabology preserved its main tenets throughout the history of the heresy, but other Bogomil doctrinal traditions (such as cosmogonic notions and narratives) were not a stable fixed system and had a more fluid, heterogeneous charcater.

Such research on the dynamics of the inter-relations between Slavo-Byzantine parascriptural literature and Bogomilism has major implications for the study of medieval Western Christian dualism in several significant spheres, areas, including, for example, the perceived (or constructed) and verifiable links between heresy and literacy in medieval Christendom. ${ }^{22}$ It is also of considerable importance to the continuing scholarly debates concerning the character, trajectories and time-line of the inter-connections between Eastern and

20 A. Miltenova, "Paratextual Literature In Action: Historical Apocalypses with the Names of Daniel and Isaiah in Byzantine and Old Bulgarian Tradition (11th-13th Centuries)," in: In the Second Degree, eds. Alexander, Lange, and Pillinger, pp. 267-284; eadem, "Intertextuality in the Orthodox Slavic Tradition: The Case of Mixed-Content Miscellanies," in: Between Text and Text, ed. Bauks, Horowitz and Lange, pp. 314-328; see also the relevant contributions on the typology, terminology and genre specifications employed in the field of the study of Old Slavonic apocryphal literature in Biblia Slavorum Apocryphorum. I. Vetus Testamentum, Fundamenta Europaea, z. vi/viI, 4, eds. A.W. Mikołajczak and M. WalczakMikołajczakowa, Łodź, 2007; G. Minczew, M. Skowronek, and I. Petrov, Biblia Slavorum Apocryphorum. II. Novum Testamentum, Łodź, 2009.

21 See A.E. Naumow, Apokryfy w systemie literatury cerkiewnoslowianskiej [The Apocrypha in the System of Church Slavonic Literature], Wrocław, 1976, and the more recent treatment of the problematics in A. Miltenova, "Marginality, Intertextuality, Paratextuality in Medieval Bulgarian Literature," in: Marginality in/of Literature, ed. R. Kuncheva, Sofia, 2011, pp. 108133 .

See note 6 above. 
Western Christian medieval dualism. These debates have intensified in the last two decades or so with the reinstatement of the minimalist or hyper-critical theories of the distinctive traits, dissemination and perceptions of Christian dualist heresy in medieval Western Christendom. Re-asserting some earlier positions, these approaches call into question or even largely negate the existence of an actual and consistent dualist theology or doctrinal system, actual organizational structures and hierarchy among communities, groups or individuals described as 'Cathar' in medieval Catholic polemical, inquisitorial and historical sources. ${ }^{23}$

The productive and useful features of what has been described also as the "inventionist" or "deconstructivist" theory of medieval Western dualist heresy include a re-accentuated critical focus on some (but not all) of the major primary sources, their socio-religious and socio-political dimension and underlying agendas. This reappraisal of the relevant source material on occasions has resorted to the application of innovative empirical and theoretical methods of enquiry and has stimulated wider, lively inter-disciplinary debates in the field of Western medieval studies. These reappraisal and debates have enriched and deepened understanding of several areas in the exploration of medieval religious dissent such as the rhetorical and literary strategies employed for the "diagnosis" and the repression of heresy and deviance in elite ecclesiastical and secular policies and discourses. Other related areas which have similarly benefited include the dynamics of heresy suppression and authority, the reiteration of late antique heresiological exemplars and clichés in medieval antiCathar polemics, the fashionable topic of "lived religion", the development of non-conformist and local group identities, the sociology and socio-economy of individual and community religious behaviour and practice.

However, the source-criticism and theory-driven analysis underpinning the arguments that medieval Western dualist heresy was predominantly a Catholic clerical construct imposed on a variety of groups perceived or charged as dissdent and Cathar has so far not included a text-critical scrutiny of the various parabiblical narratives or motifs in the primary internal and external sources on Catharism which clearly or potentially stem from earlier pseudepigraphic texts. This is undoubtedly an inexplicable neglect of vital primary source material which has been consistently the subject of attention of any serious critical investigation of the narrative traditions representing the so-called mythological complex of notions and accounts in the historical and doctrinal records of

23 See the contributions discussing the current state of evidence, research and contrasting perspectives on this problematic in Cathars in Question, ed. Sennis, especially, P. Biller, “Goodbye to Catharism?," pp. 274-314. 
western medieval dualism. ${ }^{24}$ This obvious lapse seems even more problematic in the light of the sweeping nature of pronouncements that Cathar dualist theology was forged in Catholic polemical and inquisitorial discourses, pronouncements apparently made without any preliminary assessment of the textual history and provenance of this highly relevant doctrinal and narrative material. Downplaying or dismissing outright this type of evidence generates further methodological and historiographic problems when it leads to arguments and conclusions based on the study of local archival collections to be randomly transposed, across communities and regions, to be applied as a generalization across the entire field of medieval Western dualist heresy.

This lack of examination of the parascriptural material in the sources for Western dualist heresy in the minimalist and deconstructivist approaches to Catharism seems at least to some extent conditioned by the nature of the sources themselves and their difference from the respective primary evidence in Eastern Christendom. Some of the source material for Western dualist heresy is comparable to that in Eastern Christendom (historical chronicles, sermons, treatises and acts of synods) but much of it belongs to different genres and categories: summas, papal bulls, legal consultations, inquisitors' manuals, inquisition trials' records, etc. Some of this latter material, especially the inquisitorial interrogatories and notebooks, have attracted some serious attention in Western heresy studies, and given the nature of the material, also allowed for the useful applications of methods developed over some period of time in the areas of sociology and social and cultural anthropology.

However, attempts to integrate the outcomes and achievements of the study of medieval Eastern and Western Christian literary history and pseudepigraphy into the field of Western heresy has been far less pronounced. In addition, the growing compartmentalization of scholarship in general has meanwhile limited the scope of and interest in comparative enquiries (and their potential

24 See, for, example, Loos, Dualist Heresy, chs. 7 and 11; Bozóky Le Livre secret, pp. 186-217; eadem, "La part du mythe dans la diffusion du catharisme," Heresis, 35 (2001), pp. 45-58; Stoyanov, The Other God, pp. 262-287, passim; B. Hamilton, "Wisdom from the East: the Reception by the Cathars of Eastern Dualist Texts," in: Heresy and Literacy, ed. Biller and Hudson, pp. 38-61; idem, "Old Testament Histiory: A Cathar Dilemma," Scripta \& e-Scripta, 12 (2013), pp. 211-226; L. Paolini, "Italian Catharism and Written Culture," in: Heresy and Literacy, ed. Biller and Hudson, pp. 87-103; H. Fichtenau, Heretics and Scholars in the High Middle Ages, 1000-1200, transl. D.A. Kaiser, University Park, Penn., 1998, pp.155-172; M. Lambert, The Cathars, Oxford, 1998, pp. 163 ff, 197 ff; A. Greco, Mitologia catara: il favoloso mondo delle origini, Spoleto, 2000; P. Jiménez-Sanchez, Les catharismes: modèles dissidents du christianisme médiéval (XII ${ }^{e}$-XIII ${ }^{e}$ siècles, Rennes, 2008, pp. 215-254. 
to be up-to-date), hence those working in the sphere of Western heresy have been less capable of following new developments and freshly published sources in the field of Eastern Christian heresy, even when it is immediately relevant or of equivalent historical character - such as chronicles' accounts or heresy trial records. This insufficiently balanced research focus has negatively affected the current state and prospects of medieval heresy research, especially in the comparative spheres. This is especially unfortunate in view of the similar challenges and problems posed by the external sources for Western and Eastern Christian medieval dualism respectively. These usually concern (but not only) the application and adaptation (to new religio-historical contexts) of earlier heresiological models in medieval polemical works when they encountered and needed to define and censure cases of confessional non-conformity and deviance, real, perceived or constructed. Further comparative insights into the parallels and contrasts between medieval Roman Catholic and Eastern Orthodox discourses on heresy (and their underlying agendas, rhetorical techniques and changing intertextualities) will undoubtedly greatly benefit both areas of inquiry.

Characteristically, Byzantine heresiology could exhibit dependence on late antique polemical exemplars and adopt its cliches and labels but also could dwell on and endeavour to describe and refute actual heretical teachings. ${ }^{25}$ Euthymius Zigabenus' section against the Paulicians in his twelfth-century Panoplia Dogmatica, for example, though drawing on an earlier tract, Contra Manichaeos, of Patriarch Photius (856-867; 877-886), was far from an anachronistic reproduction of its text but represented a "meticulously composed re-working" of its original sections, integrating in addition, valuable contemporaneous data concerning twelfth-century Paulician communities. ${ }^{26}$

25 For a detailed discussion of the use of heresy designations in Byzantine heresiology, its main patterns and tendencies as well as the still unresolved research questions it poses, see A. Cameron, "How to Read Heresiology," Journal of Medieval and Early Modern Studies, $33 / 3$ (2003), pp. 471-492. For arguments that heresiological labelling in the Comenian era in the twelfth century represented part of a greater imperial project to introduce categorization of the 'other'/'outsider' in the Byzantine oikoumene in the contemporary shifting religio-political climate, see H. Kusabu, Comnenian Orthodoxy and Byzantine Heresiology in the Twelfth Century: a Study of the Panoplia Dogmatica of Euthymios Zigabenos, unpublished PhD diss., University of Chicago, 2013.

26 Analysis in H. Kusabu, "Panoplia Syndrome and Comnenian Orthodoxy: Photios in the Dogmatike Panoplia," Paper presented at the Workshop on Late Antiquity and Byzantium, University of Chicago, 2008; Kusabu, Comnenian Orthodoxy and Byzantine Heresiology, pp. 119-131. 
Similar in-depth text-critical analyses and balanced research methodology are certainly needed to examine and assess the various parascriptural narratives and related literary accounts in the sources for medieval Eastern and Western Christian dualist heresy, and their theological and literary ramifications for medieval heretical (and normative) religiosities. Among other things, the conscious and inventive appropriation of varied concepts, imagery and motifs from earlier pseudepigraphic works in Eastern Christian dualism presents a series of suggestive examples of hermeneutical and compilatory strategies of using and adapting scriptural and parascriptural texts which are of obvious importance for the exploration of the related or similar parabiblical narratives in the evidence of Catharism. Such exploration will need to re-emphasize and expand the text-critical scrutiny of these layers in the primary sources for Catharism as well as to re-focus on the vital related issues of reconstructing (whenever possible) textual histories and reassessment of the patterns of the verifiable or possible intra-cultural transmission of such parabiblical material.

The application of up-to-date text-critical methods to this material will allow in the first place a reappraisal of the arguments that it represents conclusive evidence of imported dualist teachings and narratives in Catharism. In this manner the parascriptural material in the sources for Catharism could be duly incorporated in the wider and growing study of the eastern and western trajectories of parabiblical literature and pseudepigraphy (and related and derivative oral traditions) in medieval European Christendom in general. ${ }^{27}$ The various textual questions arising from the provenance and function of this material need to be properly addressed, since strong criticism has been launched at some recent sweeping reconstructions of Cathar history and doctrines (or the lack of them) made on the basis of incomplete evidence (or incomplete use of the extant evidence) ${ }^{28}$ Hence the issues of linguistic and stylistic nature, the problems of editorial intrusions and reworkings, as well as credible

27 On the significance of the 'surplus', non-formulaic material in sources for Western dualism such as the inquisition depositions (including parascriptural material), cf. C. Bruschi, The Wandering Heretics of Languedoc, Cambridge, 2009, passim; P. Biller, "Cathars and the Material World," in: God's Bounty? The Churches and the Natural World. Papers Read at the 2008 Summer Meeting and the 2009 Winter Meeting of the Ecclesiastical History Society, eds. P. Clarke and T. Claydon, Woodbridge, 2010, pp. 89-110; C. Taylor, "Evidence for Dualism in Inquisitorial Registers of the 1240s: A Contribution to a Debate," History, 98 (2013), pp. 319345, passim; eadem, "Heresy in Quercy in the 1240s: Authorities and Audiences," in: Heresy and the Making of European Culture, Medieval and Modern Perspectives, ed. A.P. Roach and J.R. Simpson, London, 2013, pp. 239-257, passim. 
and potential markers of cross-cultural transmission and translation require a balanced, in-depth treatment. Assessing this western source material in such wider cultural and literary framework will be also very beneficial for some promising areas of Cathar studies where research has not moved much beyond its nascent stages. 